\title{
Host and Non-Host Disease Resistances of Kimchi Cabbage Against Different Xanthomonas campestris Pathovars
}

\author{
Young Hee Lee and Jeum Kyu Hong* \\ Department of Horticultural Sciences, Gyeongnam National University of Science and Technology (GNTech), Jinju 660-758, \\ Korea
}

(Received on April 1, 2012; Revised on May 31, 2012; Accepted on May 31, 2012)

This study was conducted to investigate host and nonhost disease resistances of kimchi cabbage plants to bacterial infection. Kimchi cabbage leaves responded differently to infections with a virulent strain of Xanthomonas campestris pv. campestris (Xcc) 8004 and two strains (85-10 and Bv5-4a.1) of non-host bacteria $X$. campestris pv. vesicatoria (Xcv). Non-host bacteria triggered a rapid tissue collapse of the leaves showing as brown coloration at the infected sites, highly increased ion leakage, lipid peroxidation and accumulation of $\mathrm{UV}$ stimulated autofluorescence materials at the inoculated sites. During the observed interactions, bacterial proliferations within the leaf tissues were significantly different. Bacterial number of Xcc 8004 progressively increased within the inoculated leaf tissues over time, while growths of two non-host bacteria Xcv strains were distinctly limited. Expressions of pathogenesis-related genes, such as GST1, PR1, BGL2, VSP2, PR4 and LOX2, were differentially induced by host and non-host bacterial infections of $X$. campestris pathovars. These results indicated that rapid host cellular responses to the nonhost bacterial infections may contribute to an array of defense reactions to the non-host bacterial invasion.

Keywords : kimchi cabbage, non-host disease resistance, programmed cell death, Xanthomonas campestris pathovars

Plants protect themselves actively against non-host pathogens via an array of defense reactions, which are sometimes similar to those against host pathogen infections. So far, non-host disease resistance have been classified into two types in diverse plant species (Mysore and Ryu, 2004; Oh et al., 2006). Type I and type II non-host disease resistance is differentiated by appearance of visible cell death in response to infections by non-host fungal and bacterial pathogens. Hypersensitive cell death was not found in type I non-host resistance, while rapid cell death usually observed

\footnotetext{
*Corresponding author.

Phone) +82-55-751-3251, FAX) +82-55-751-3257

E-mail)jkhong@gntech.ac.kr
}

in incompatible interactions between hosts and avirulent strains appear in type II non-host resistance. During cell death-mediated non-host disease resistance, host plants launched sophisticated defense mechanisms i.e. oxidative burst, kinase cascades and accumulation of antimicrobial proteins usually found during incompatible interactions of host plant-pathogen (Dixon et al., 1994).

Non-host disease resistance of kimchi cabbage plants were previously reported against infection by Pseudomonas syringae pv. tomato (Pst) (Park et al., 2005). Hypersensitive cell death and accumulation of $\mathrm{H}_{2} \mathrm{O}_{2}$ appeared in the leaf tissue of kimchi cabbage within $24 \mathrm{~h}$ after non-host bacterial invasion. Expressions of pathogenesis-related genes encoding thaumatin-like protein (TLP) and pathogenesisrelated (PR) protein 4 increased distinctly by non-host Pst infection. However, non-host defenses triggered by different pathovars of the same species of phytopathogenic bacteria have not been described in kimchi cabbage plants.

In this study, we used three different pathovars of Xanthomonas campestris mediating basal resistance and non-host disease resistance in kimchi cabbage plants. $X$. campestris pv. campestris (Xcc) infects various cruciferous plants including Arabidopsis (Simpson and Johnson, 1990), cabbage (Bretschneider et al., 1989) and rapeseed (Lema et al., 2011), causing chlorosis and black rot symptoms. However, $X$. campestris pv. vesicatoria $(\mathrm{Xcv})$ invades pepper and/or tomato plants to cause bacterial spots in the infected leaves but does not infect cruciferous plants (Stall et al., 2009). We inoculated the leaves using a scissor-clipping method with bacterial suspensions $\left(10^{8} \mathrm{cfu} / \mathrm{ml}\right)$ supplemented with $0.05 \%$ of Tween 20 as a surfactant to mimic natural vascular invasion of Xcc (Dow et al., 2003). After leaf-clipping, kimchi cabbage seedlings were placed in moist chamber for $48 \mathrm{~h}$ and returned to a growth room for symptom development. Clear difference in disease development to the host and non-host $X$. campestris pathovars were observed in the kimchi cabbage leaves (Fig. 1A). At 7 days post-inoculation (dpi), the first visible symptoms appeared at the Xcc 8004 inoculated leaves, and progressive chlorotic symptoms with typical V-shape lesions developed around 

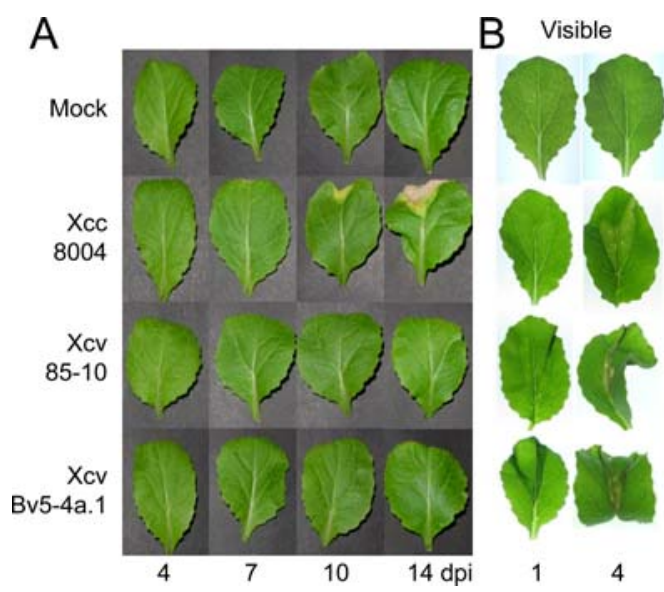

Ethanol-cleared

Fig. 1. Different disease responses of kimchi cabbage leaves against infections by $X$. campestris pv. campestris (Xcc) strain 8004 and two non-host strains $85-10$ and Bv5-4a.1 of $X$. campestris pv. vesicatoria (Xcv). Symptom development was observed in primary leaves of kimchi cabbage plants infected with high concentrations $\left(10^{8} \mathrm{cfu} / \mathrm{ml}\right)$ of Xcc 8004 , Xcv 85-10 and Xcv Bv5-4a.1 using (A) leaf clipping-inoculation method and (B) syringe-infiltration method. Photos were taken at indicated day point in the figure. Chlorophylls of the inoculated leaves were removed with ethanol to clearly visualize brownish color development after syringe-infiltration.

main vein of the leaves inoculated by Xcc 8004 at 10-14 dpi. In contrast, the two Xcv 85-10 and Xcv Bv5-4a.1 strains did not induce any visible disease symptoms or hypersensitive response (HR)-like lesion in the kimchi cabbage leaves. Symptom development in the primary and secondary leaves looked similar to each other (data not shown). These indicated kimchi cabbage is a non-host plant for these two Xcv strains without showing any significant symptomatic appearance mediated by natural infection through hydathodes and veins. Although differential disease responses distinctly occurred by host and non-host $X$. campestris infections, we could not conclude this was due to suppression of non-host Xcv proliferation within plant tissues by non-host disease resistance of kimchi cabbage leaves or only the inability of this organism to enter the vascular structures of the leaves, because Xcv naturally invades plant tissues through stomata and/or mechanical wounds (Ramos and Volin, 1987; Vakili, 1967).

To investigate cell-to-cell responses of kimchi cabbage mesophyll leaf tissues upon inoculations with host and nonhost $X$. campestris pathovars, leaves of 2-week-old kimchi cabbage seedlings were syringe-infiltrated with high doses $\left(10^{8} \mathrm{cfu} / \mathrm{ml}\right)$ of bacterial suspensions of three different strains, Xcc 8004, Xcv 85-10 and Xcv Bv5-4a.1 (Fig. 1B). No significant symptom development was found in the kimchi cabbage leaves infected by Xcc 8004 at 1 dpi, and then tissue collapse with mild chlorotic lesion appeared at 4 dpi. With non-host bacteria Xcv 85-10 infection, kimchi cabbage leaf tissues did not show drastic response at 1 dpi, but showed water-soaked tissue collapse with a browning coloration at 4 dpi. kimchi cabbage leaves responded hypersensitively against infection with the Xcv Bv5-4a.1 strain, demonstrating water-soaked lesion and tissue damage at the inoculated area at $1 \mathrm{dpi}$. The leaf tissues infected by Xcv Bv5-4a.1 were severely damaged and dried at 4 dpi. To clearly visualize plant tissue damages affected by the high doses bacterial infections, inoculated kimchi cabbage leaves were cleared with 95\% ethanol (Fig. 1B). Distinct brown necrotic coloration was visible in kimchi cabbage leaves with Xcv 85-10 and Bv5-4a.1 infections at $1 \mathrm{dpi}$, but not with Xcc 8004, indicating rapid tissue damages caused by non-host bacterial inoculation. Tissue discoloration by Xcv strains became more pronounced at $4 \mathrm{dpi}$, at which time brown color also developed in kimchi cabbage leaves infected by Xcc 8004, host pathogenic bacteria. Two inoculation methods of leaf-clipping and syringe-infiltration led to different temporal symptom development although the same concentration of bacterial suspension $\left(10^{8} \mathrm{cfu} / \mathrm{ml}\right)$ was used. Only a small number of bacteria may enter through hydathodes for vascular invasion.

Ion leakage is one of the hallmarks of pathogen- and abiotic elicitor-mediated cellular disorders linked to imbalanced membrane permeability (Mur et al., 2006; Zhang et al., 2004). To investigate and quantify non-host bacteriamediated cell death in the infected region of Chinese cabbage leaf tissues, ion conductivities after pathogen infections were measured with different time course (Fig. 2). After syringe-infiltration of mock and bacterial suspensions, leaf discs were prepared immediately and floated into distilled water. Ion conductivity of the water was measured with time. No significant ion leakage was found in the leaf

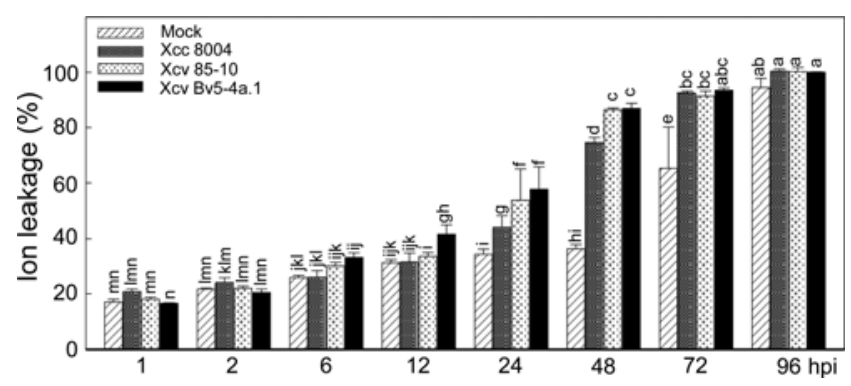

Fig. 2. Host and non-host bacteria-induced cellular damages in kimchi cabbage leaves for 4 days after inoculation by syringeinfiltration with $10^{8} \mathrm{cfu} / \mathrm{ml}$ of avirulent strain 8004 of $X$. campestris pv. campesris (Xcc), and two non-host strains 85-10 and Bv5$4 \mathrm{a} .1$ of $X . c$. pv. vesicatoria $(\mathrm{Xcv})$. Cellular damages in kimchi cabbage leaves was assessed by increasing ion leakage after inoculation with mock, Xcc 8004, Xcv 85-10 and Xcv BV5-4a.1 (each $10^{8} \mathrm{cfu} / \mathrm{ml}$ ). The data points are the mean relative ion conductivity \pm standard errors. Mean separation by Duncan's multiple range test at $P=0.05$. 
tissues inoculated by any host or non-host bacterial strains of $X$. campestris within $6 \mathrm{~h}$. Only Xcv Bv5-4a.1 increased ion leakage from the inoculated leaf tissues at 12 hours post-inoculation (hpi). Host bacterial strain Xcc 8004 triggered ion leakage at $24 \mathrm{hpi}$, but much more ion leakage occurred in leaf tissues infected by non-host bacterial strains Xcv 85-10 and Bv5-4a.1 at that time point. However, no difference was found in the conductivities by both non-host bacteria at $24 \mathrm{hpi}$. Host bacteria induced dramatic increases in ion conductivity at 48 hpi, however, ion leakage induced by Xcv strains were still higher than that for Xcc-infected leaf tissues. Ion leakages caused by two Xcv strains have not shown significant different after $24 \mathrm{~h}$ evaluated in this study. After 72-96 hpi, ion leakages by all of three strains were not distinguishably increased compared to mock-induced ion leakage. These findings from kimchi cabbage leaves inoculated with Xcc 8004, Xcv 8510 and Xcv Bv5-4a.1 strains demonstrated that drastic tissue collapse by non-host bacteria correlated with rapidly increased ion leakages triggered by non-host bacteria. In particular, Xcv Bv5-4a.1 may release stronger or more effective elicitor(s) into kimchi cabbage leaf tissues for the establishment of HR.

We conducted histochemical staining approaches for investigation of cellular responses during host and non-host bacterial resistances in kimchi cabbages against $X$. campestris infections. Lipid peroxidation of pepper leaf tissues was highly increased during incompatible interaction between pepper leaves and $X$. campestris pv. vesicatoria (Hwang and Hwang, 2010). Massive lipid peroxidation in cotton leaves was involved in the hypersensitive defense response triggered by an avirulent strain of $X$. campestris pv. malvacearum (Jalloul et al., 2002). Lipid peroxidation is a process of lipid degradation mediated by reactive oxygen species. Increased lipid peroxidation in animals and plants can indicate membrane deterioration induced by cellular injuries. Lipid peroxidation can be detected by staining with Schiff's reagent (Yamamoto et al., 2001). During the nonhost resistance to Xcv, lipid peroxidation appeared to occur at an earlier time after bacterial infections compared to that induced by Xcc (Fig. 3A), suggesting that lipid peroxidation can be biochemically indicative of programmed cell death (PCD) for plants. Membrane deterioration with lipid peroxidation can also produce endogenous fatty acid elicitors triggering host defenses (Savchenko et al., 2010). Accumulation of autofluorescent materials stimulated by $\mathrm{UV}$-irradiation have been frequently detected in plant cells undergoing cell death during various plant-pathogen interactions. Higher number of autofluorescent cells in infected host tissues were observed in the phloem and xylem cells of resistant cassava cultivar infected with $X$. campestris pv. manihotis (Kpémoua et al., 1996) and in cotton leaves

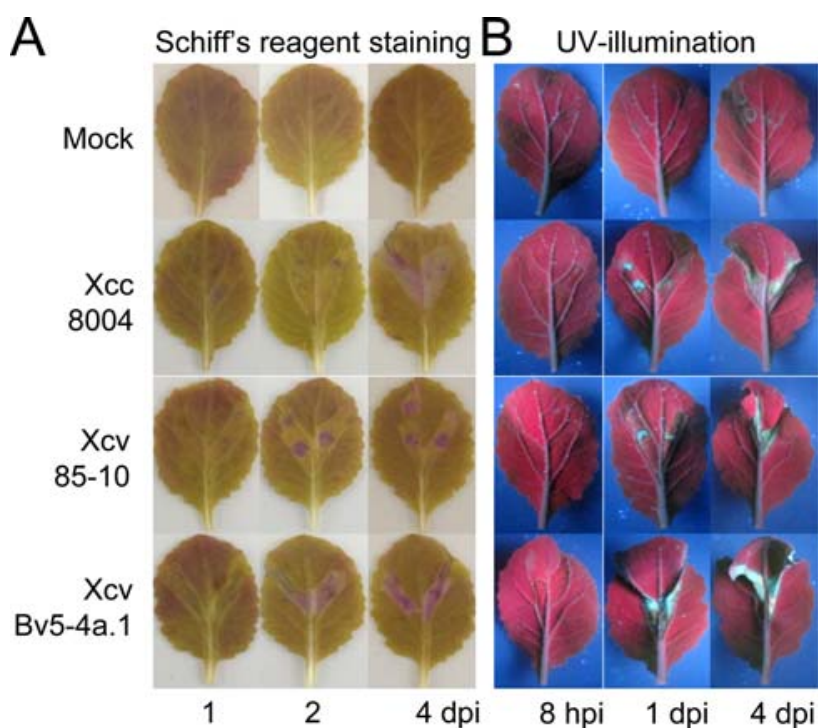

Fig. 3. Cellular response of kimchi cabbage leaves during host and non-host resistance. (A) Histochemical detection of lipid peroxidation. Kimchi cabbage leaves inoculated by syringeinfiltration with $10^{8} \mathrm{cfu} / \mathrm{ml}$ of virulent strain 8004 of $X$. campestris pv. campestris, and non-host strains 85-10 and Bv5-4a.1 of $X$. c. pv. vesicatoria were stained with Schiff's reagent. (B) Accumulation of fluorescence materials in kimchi cabbage leaves. Nonhost bacteria-induced hypersensitive response in kimchi cabbage leaves 8 hours, 1 and 4 days after inoculation by syringeinfiltration with $10^{8} \mathrm{cfu} / \mathrm{ml}$ of virulent strain 8004 of $X$. campestris, and non-host strains 85-10 and Bv5-4a.1 of X. c. pv. vesicatoria. Localized necrotic symptom on kimchi cabbage leaves was visualized by UV-illumination.

inoculated with $X$. campestris pv. malvacearum (Essenberg et al., 1992). An avirulent strain of $X$. campestris pv. campestris triggered development of autofluorescence in Arabidopsis leaf tissues (Lummerzheim et al., 1993). Kimchi cabbage leaves infected with the two different nonhost Xcv strains also showed UV-stimulated autofluorescence with a bright whitish blue coloration at the infection sites, this occurred much faster than for basal disease resistance to virulent Xcc 8004 (Fig. 3B). Autofluorescence in the Xcv Bv5-4a.1-inoculated leaves showed faster and stronger accumulation compared to other non-host bacteria Xcv 85-10-inoculated leaves. Autofluorescence in plant cells has been considered as the accumulation of phenolic compounds such as antimicrobial phytoalexins and extensive polymerization in the plant cell wall in order to inhibit bacterial invasion and growth. This indicates that activation of secondary metabolism of phenolic compounds may be involved in the non-host resistance of kimchi cabbage to Xcv. Recently, application of cellulase ClsA secreted from the bacterial rice blight causing pathogen $X$. oryzae pv. oryzae resulted in HR-like symptom and ligninlike autofluorescence in rice leaves (Jha et al., 2007). Xcvoriginated elicitors for PCD and the accompanied auto- 
fluorescence in the kimchi cabbage leaves remains to be elucidated. Both cytological findings of the prominent increases in lipid peroxidation and accumulation of autofluorescence compounds at the local infected sites by nonhost $X$. campestris pathovars suggested that Chinese cabbage leaves response rapidly and actively to combat the incompatible microbial pathogens through fatty acid- and phenolics-mediated defense responses.

Bacterial proliferation within plant leaf tissues was evaluated to determine whether host- and non-host $X$. campestris pathovars grow differently (Fig. 4). The abaxial leaf surfaces of fully expanded primary leaves of 2-weekold kimchi cabbage seedlings were syringe-infiltrated with $10^{5} \mathrm{cfu} / \mathrm{ml}$ of bacterial suspension. Symptoms on the leaves developed differently caused by lower dose of bacterial inoculations of Xcc 8004, Xcv 85-10 and Xcv Bv5-4a.1 (Fig. 4A). Xcc 8004 induced slight chlorosis at the inoculated site at $10 \mathrm{dpi}$ and lesions became brownish and dried at $14 \mathrm{dpi}$. Infection with the two non-host Xcv strains did not result in any visible symptoms on the leaves. Bacterial colonies from a serial dilution assay were counted and bacterial numbers per $\mathrm{cm}^{2}$ were compared during hostand non-host disease resistance. Differential bacterial growth was demonstrated in the kimchi cabbage leaves (Fig. 4B). Xcc 8004 first started to proliferate at $2 \mathrm{dpi}$, and much increased in colony number by $4 \mathrm{dpi}$. At 7-10 dpi, the bacterial population reached a plateau, and then drastically decreased by 14 dpi. Bacterial proliferation of Xcv 85-10 did not occur until $10 \mathrm{dpi}$, and a small increase in bacterial number was found at $14 \mathrm{dpi}$. Increase of Xcv Bv5-4a.1 bacterial growth was much faster than for Xcv 85-10, and began to slightly increase at $4 \mathrm{dpi}$. However, bacterial growth of Xcv Bv5-4a.1 was arrested until 7-14 dpi. This indicated that growths of the non-host bacterial pathovars were severely arrested in the kimchi cabbage leaf tissues.

We investigated the expressions of several pathogenesisrelated (PR) genes encoding glutathione- $S$-transferase (GST1), pathogenesis-related protein $1(P R 1)$, basic glucanase (BGL2), vegetative storage protein 2 (VSP2), pathogenesis-related protein $4(P R 4)$ and lipoxygenase 2 (LOX2) during the host and non-host interactions with different $X$. campestris pathovars to investigate association of PR gene inductions with host and non-host disease resistance in kimchi cabbage plants. RT-PCR analyses demonstrated that these defense-related genes were differentially regulated in kimchi cabbage leaves infected with Xcc and Xcv

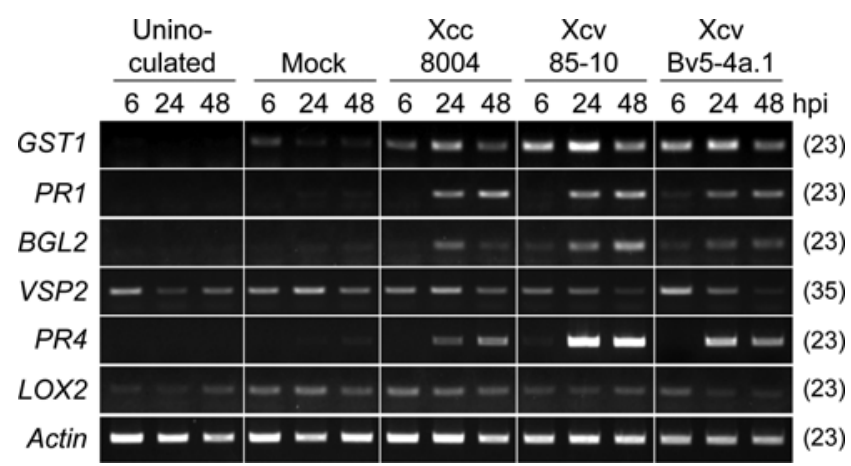

Fig. 5. Expression of defense-related genes during host and nonhost resistance of kimchi cabbage plants. RT-PCR analysis of glutathione-s-transferase (GST1), pathogenesis-related protein 1 $(P R 1)$, basic glucanase $(B G L 2)$, vegetative storage protein 2 (VSP2), pathogenesis-related protein 4 (PR4) and lipoxygenase 2 $(L O X 2)$ genes in kimchi cabbage leaves inoculated with different $X$. campestris pathovars. Actin was used as an amplification control. Mock, sterile water-infiltrated; Xcc 8004, X. campestris pv. campestris; Xcv 85-10, X. campestris pv. vesicatoria strain 8510; Xcv Bv5-4a.1, X. campestris pv. vesicatoria strain Bv5-4a.1. The number of PCR cycles of each result is indicated in the parenthesis.
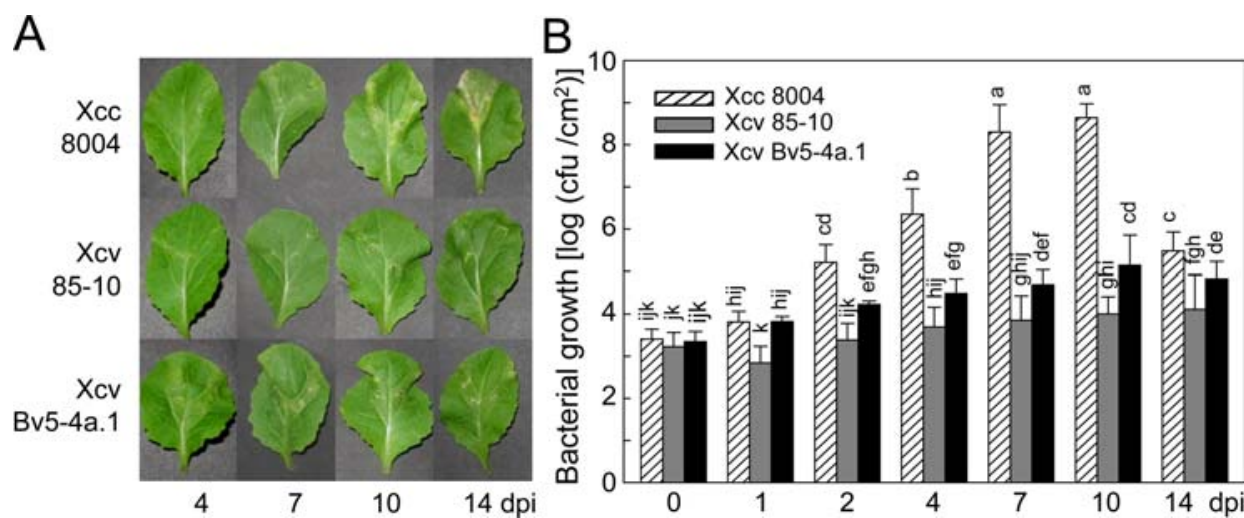

Fig. 4. Disease response of kimchi cabbage leaves against low doses $\left(10^{5} \mathrm{cfu} / \mathrm{ml}\right)$ of bacterial infections. (A) Symptom development on the inoculated leaves by the virulent strain 8004 of Xanthomonas campestris pv. campestris and non-host strains 85-10 and Bv5-4a.1 of Xanthomonas campestris pv. vesicatoria. (B) Time courses of bacterial growth in the primary leaves of kimchi cabbage challenged with the virulent strain 8004 of Xanthomonas campestris pv. campestris and non-host strains 85-10 and Bv5-4a.1 of Xanthomonas campestris pv. vesicatoria. The data points are the mean bacterial numbers \pm standard errors. Mean separation by Duncan's multiple range test at $P=0.05$. 
Table 1. Nucleotide sequences of oligonucleotide primers used for RT-PCR to detect kimchi cabbage genes encoding defense-related proteins

\begin{tabular}{|c|c|c|c|}
\hline $\begin{array}{l}\text { Gene } \\
\text { name }\end{array}$ & $\begin{array}{l}\text { Protein } \\
\text { product }\end{array}$ & $\begin{array}{l}\text { Accession } \\
\text { number }\end{array}$ & $\begin{array}{l}\text { Sequence } \\
\left(5^{\prime} \text { to } 3^{\prime}\right)\end{array}$ \\
\hline GST1 & $\begin{array}{l}\text { glutathione-S- } \\
\text { transferase }\end{array}$ & AY567976 & $\begin{array}{l}\text { F: TCAATGGCAGGTATCAAAGT } \\
\text { R: TCACTGAAGGATCTTCTGGG }\end{array}$ \\
\hline PR1 & $\begin{array}{l}\text { pathogenesis-related } \\
\text { protein } 1\end{array}$ & BBRAF03K11 & $\begin{array}{l}\text { F: TACGCTCAAAACTACGCCGA } \\
\text { R: GAAAGGTCCCCGCTACTTCC }\end{array}$ \\
\hline$B G L 2$ & basic glucanase & BBRAF10P08 & $\begin{array}{l}\text { F: GCAGAACATCGATAGAGCGGT } \\
\text { R: TGAATGTCCCACTCGAAGGC }\end{array}$ \\
\hline VSP2 & $\begin{array}{l}\text { vegetative storage } \\
\text { protein } 2\end{array}$ & EX103556 & $\begin{array}{l}\text { F: GACTCCAAAACGGTGTGCAAA } \\
\text { R: AGGGTCTCGTCAAGGTCAAAGA }\end{array}$ \\
\hline PR4 & $\begin{array}{l}\text { pathogenesis-related } \\
\text { protein } 4\end{array}$ & AF528181 & $\begin{array}{l}\text { F: GCATATGTTTGTTGGTGTTGC } \\
\text { R: CAGTTGACAAACTCGTAGTTGA }\end{array}$ \\
\hline$L O X 2$ & lipoxygenase 2 & EX100417 & $\begin{array}{l}\text { F: TCCCCACTTCCGCTACACC } \\
\text { R: AATACTTTCCGGGCCAGAAAC }\end{array}$ \\
\hline Actin & actin & & $\begin{array}{l}\text { F: ACTCATATGTTGGAGATGAAGCGCA } \\
\text { R: AATGTTACCATACAAATCCTTACGGA }\end{array}$ \\
\hline
\end{tabular}

strains (Fig. 5). GST catalyzes nucleophilic attack of the tripeptide glutathione on lipophilic compounds with electrophilic centers, to detoxify primarily endogenous and xenobiotic compounds (Edwards et al., 2000). GST1 expression was induced in Arabidopsis leaves inoculated by non-host fungus Blumeria graminis f.sp. tritici. However, it was attenuated in defense-deficient mutants eds 1 and pad4 (Yun et al., 2003). Up-regulation of kimchi cabbage GST1 gene was triggered by non-host bacteria Xcv 85-10 was very high. GST1 inductions with Xcv Bv5-4a.1 and the host bacteria Xcc strain were modest. GST may be efficiently contributed to detoxification of metabolites produced in kimchi cabbage leaves by Xcv 85-10 inoculation, whereas it is not closely related to Xcv Bv5-4a.1-mediated cell death and disease resistance. PR1 protein has been considered as a molecular marker for disease resistance in many plants despite unknown function (van Loon and van Strien, 1999). PRl-like gene BrPRl in kimchi cabbage was induced by salicylic acid (SA), not by jasmonic acid (JA) and ethylene, implying role in plant defense against biotrophic pathogen infections (Abe et al., 2011). BrPR1 expression during host and non-host resistance to $X$. campestris pathovars was not different in leaves inoculated by host and non-host strains. $\beta$-1,3-Glucanase hydrolyzes $\beta$-1,3-glucan, a major component of bacterial and fungal cell walls, by cleavage of $1,3-\beta-$ D-glucosidic linkages, and is considered as one of the major classes of plant PR proteins (van Loon et al., 2006). Oligosaccharides derived plant cell wall $\beta$-1,3-glucan by bacterial exoenzymes can mediate defense cascades as endogenous elicitors and act to coordinate disease resistance to combat challenging pathogens (Palva et al., 1993). Inducible expression of a $\beta$-1,3-glucanase gene in turnip leaves infected with Xcc 8004 was mediated by an extracellular endoglucanase originating from the bacterial strain (Newman et al., 1994). Expression of the BGL2 gene encoding a putative basic glucanase was analyzed in the leaf tissues of kimchi cabbage plant challenged by the bacteria. The BGL2 mRNA accumulated with Xcc 8004, Xcv 85-10 and Xcv Bv5-4a.1 inoculations at 24 hpi, but BGL2 mRNA accumulation was significantly increased by Xcv 85-10 at 48 dpi. In the leaves of the Arabidopsis ecotype Col-0, glucanase was only transiently up-regulated by an avirulent strain Xcc 147, but not by the virulent strain Xcc 8004 at 48 dpi (Lummerzheim et al., 1993). Glucanase enzyme activity was increased in turnip leaves by host bacteria Xcc 8004 infection. However, much higher activation of the enzyme was detected in leaves infected with the non-host bacteria $X$. campestris pv. vitians, the causal agent of bacterial leaf spot of lettuce (ConradsStrauch et al., 1990). Transient induction of in the kimchi cabbage leaves by Xcc 8004 at 24 hpi. Xcv 85-10-induced $B G L 2$ expression at $24 \mathrm{hpi}$ increased at 48 hpi. Recently, Abe et al. (2011) demonstrated that $B r B G L 2$ was inducible by SA but minute increase of $B r B G L 2$ transcripts was observed by JA and ethylene. It is well known that one signaling pathway synergistically and negatively interacts with others in plant defenses (Dong, 1998; Luo et al., 2011). Usually SA-dependent defense pathway was antagonistic to JA/ethylene-dependent pathways. We investigated expression of three defense-related genes, VSP2, PR4 and $L O X 2$, which are induced by JA and/or ethylene. VSP2 and $P R 4$ are inducible in kimchi cabbage leaves by JA and ethylene, respectively, and $L O X 2$ expression is increased by both elicitors (Abe et al., 2011; Park et al., 2005). VSP play a role as proteinaceous storage reserves buffering availability of nitrogen and other nutrients. VSP2 gene increased in Arabidopsis inoculated by fungal necrotroph Alternaria brassicicola, but the biotrophic oomycete Hyaloperonospora 
parasitica infections did not lead to VSP2 expression indicating its expression was differentially regulated by pathogens with different life styles (Koornneef et al., 2008). VSP2 was also preferentially induced by avirulent bacteria P. syringae pv. tomato (Truman et al., 2007). The two nonhost $X$. campestris strains specifically reduced the VSP2 gene expressions in kimchi cabbage leaves compared to that in the mock-inoculated leaves, which is might be mediated by antagonistic suppression of JA signaling by enhanced SA signaling. PR4 proteins include structurally chitinase-like families associated with plant disease resistance showing direct antifungal activities or RNase/DNase activities (Guevara-Morato et al., 2010; Li et al., 2010). The $P R 4$ gene or $P R 4$ gene families were also involved in biotic and abiotic stress responses in many plant species including rice (Wang et al., 2011) and wheat (Bertini et al., 2011). Non-host necrotrophic fungus Plectosphaerella cucumerina inoculation led to increasing accumulation of PR4 transcripts in Arabidopsis (Sanchez-Vallet et al., 2010). The PR4 gene significantly was induced by non-host Pst infection and ethylene in kimchi cabbage leaf tissues (Park et al., 2005). However its comparative expression during basal disease resistance against virulent host bacterial infection was not demonstrated in the previous study. During the host and non-host disease resistance in the kimchi cabbage leaves, $P R 4$ gene increased earlier and stronger during infection with the two non-host $X$. campestris pathovars. Xcv 85-10 induced much higher level of PR4 transcript than Xcv Bv5-4a.1 did. Lipoxygenase catalyzes polyunsaturated fatty acids into hydroperoxides followed by oxylipins to mediate plant defense. Lipoxygenase activity drastically increased in the cotton and pepper leaves during incompatible interactions with $X$. campestris pv. malvacearum and $X$. campestris pv. vesicatoria, respectively (Hwang and Hwang, 2010; Jalloul et al., 2002). Lipid peroxidation during these interactions was intimately correlated with increased lipoxygenase activity in the plant tissues underwent hypersensitive cell death. Chinese cabbage LOX2 gene expression was found to be specifically repressed in the leaves compared to that in the mockinoculated leaves. It is similar to the $V S P 2$ gene expression in the leaves inoculated by the non-host strains, indicating JA signaling is down-regulated during Xcv-mediated nonhost resistance. Preferential expression of GST1, BGL2 and PR4 genes to $\mathrm{Xcv}$ strains suggested that these genes function coordinately during establishment of non-host disease resistance of kimchi cabbage through activation of SA- and ethylene-dependent signaling pathways, which are antagonistic to JA-dependent pathways. Defense signaling cross-talk during the host and non-host resistance of kimchi cabbage plants remains elucidated.

Interestingly, higher PR gene activations and severely arrested bacterial growth were found in leaf tissues inoculated with Xcv 85-10 compared to those by Xcv Bv5-4a.1, although Xcv Bv5-4a.1 triggered much more rapid HR showing accelerated ion leakages, lipid peroxidation and accumulation of phenolic compounds. These findings suggest that non-host disease resistances of kimchi cabbage against $X$. campestris pathovars are partially uncoupled with cell death reprogramming. Recently, novel genes involved in non-host disease resistance were isolated from tobacco plants infected by $X$. axonopodis pv. citri, causing citrus canker, via transcriptome analysis (Daurelio et al., 2011). Lack of incompatible interaction of kimchi cabbage with an avirulent strain of $X$. campestris pv. campestris have impeded the understanding of the basis of disease resistance mechanisms so far. Further transcriptional profiling in the kimchi cabbage plants infected by host Xcc 8004 and non-host Xcv 85-10 and Bv5-4a.1 will provide molecular clues for active defense machinery.

In conclusion, kimchi cabbage plants have basal and nonhost disease resistance to $X$. campestris pv. campestris and to $X$. campestris pv. vesicatoria, respectively. Non-host resistance to infections with different $X$. campestris pathovars resulted in PCD, accompanied with rapid cellular and molecular responses. Molecular and cellular details on the non-host disease resistance to different $X$. campestris pathovars remain elusive. The plant-pathogen interactions introduced in the current study will provide more insights on disease resistance mechanism of kimchi cabbage plants.

\section{Acknowledgements}

We are grateful to professor Max Dow (University College Cork, Ireland) for kindly providing the Xcc 8004 strain, and to Dr. Yiqin Wang (Institute of Genetics and Developmental Biology, Chinese Academy of Sciences, China) and Dr. Hazel McLellan (Division of Plant Sciences, University of Dundee, United Kingdom) for the helpful discussion and critical reviewing our manuscript. This research was supported by a grant from The Agricultural Genome Center (TAGC), in the Next-Generation BioGreen21 Program (grant no. PJ008211), Rural Development Administration, Republic of Korea, and Basic Science Research Program through the National Research Foundation of Korea (NRF) funded by the Ministry of Education, Science and Technology (grant no. 2010-0003285), Republic of Korea.

\section{References}

Abe, H., Narusaka, Y., Sasaki, I., Hatakeyama, K., Shin-I, S., Narusaka, M., Fukami-Kobayashi, K., Matsumoto, S. and Kobayashi, M. 2011. Development of full-length cDNAs from Chinese cabbage (Brassica rapa subsp. pekinensis) and identi- 
fication of marker genes for defense response. DNA Res. 18:277-289.

Bertini, L., Cascone, A., Tucci, M., D’Amore, R., Di Berardino, I., Buonocore V, Caporale, C. and Caruso, C. 2011. Molecular and functional analysis of new members of the wheat PR4 gene family. Biol. Chem. 387:1101-1111.

Bretschneider, K. E., Gonella, M. P. and Robeson, D. J. 1989. A comparative light and electron microscopical study of compatible and incompatible interactions between Xanthomonas campestris pv. campestris and cabbage (Brassica oleracea). Physiol. Mol. Plant Pathol. 34:285-297.

Conrads-Strauch, J., Dow, J. M., Milligan, D. E., Parra, R. and Daniels, M. J. 1990. Induction of hydrolytic enzymes in Brassica campestris in response to pathovars of Xanthomonas campestris. Plant Physiol. 93:238-243.

Daurelio, L. D., Petrocelli, S., Blanck, F., Holuigue, L., Ottado, J. and Orellano, E. G. 2011. Transcriptome analysis reveals novel genes involved in nonhost responses to bacterial infection in tobacco. J. Plant Physiol. 168:382-391.

Dixon, R. A., Harrison, M. J. and Lamb, C. J. 1994. Early events in the activation of plant defense responses. Annu. Rev. Phytopathol. 32:479-501.

Dong, X. 1998. SA, JA, ethylene, and disease resistance in plants. Curr. Opin. Plant Biol. 1:316-323.

Dow, J. M., Crossman, L., Findlay, K., He, Y. Q., Feng, J. X. and Tang, J. L. 2003. Biofilm dispersal in Xanthomonas campestris is controlled by cell-cell signaling and is required for full virulence to plants. Proc. Natl. Acad. Sci. USA 100:1099511000 .

Edwards, R., Dixon, D. P. and Walbot, V. 2000. Plant glutathione $S$-transferase: enzymes with multiple functions in sickness and in health. Trends Plant Sci. 5:193-198.

Essenberg, M., Pierce, M. L., Hamilton, B., Cover, E. C., Scholes, V. E. and Richardson, P. E. 1992. Development of fluorescent, hypersensitively necrotic cells containing phytoalexins adjacent to colonies of Xanthomonas campestris pv. malvacearum in cotton leaves. Physiol. Mol. Plant Pathol. 41:85-99.

Guevara-Morato, M. Á., de Lacoba, M. G., García-Luque, I. and Serra, M. T. 2010. Characterization of a pathogenesis-related protein (PR-4) induced in Capsicum chinense $L^{3}$ plants with dual RNase and DNase activities. J. Exp. Bot. 61:3259-3271.

Hwang, I. S. and Hwang, B. K. 2010. The pepper 9-lipoxygenase gene $C a L O X 1$ functions in defense and cell death responses to microbial pathogens. Plant Physiol. 152:948-967.

Jalloul, A., Montillet, J. L., Assigbetsé, K., Agnel, J. P., Delannoy, E., Triantaphylidés, C., Daniel, J. F., Marmey, P., Geiger, J. P. and Nicole, M. 2002. Lipid peroxidation in cotton: Xanthomonas interactions and the role of lipoxygenase during hypersensitive reaction. Plant J. 32:1-12.

Jha, G., Rajeshwari, R. and Sonti, R. V. 2007. Functional interplay between two Xanthomonas oryzae pv. oryzae secretion systems in modulating virulence on rice. Mol. Plant-Microbe Interact. 20:31-40.

Koornneef, A., Leon-Reyes, A., Ritsema, T., Verhage, A., den Otter, F. C., van Loon, L. C. and Pieterse, C. M. J. 2008. Kinetics of salicylate-mediated suppression of jasmonate sig- naling reveal a role for redox modulation. Plant Physiol. 147:1358-1368.

Kpémoua, K., Boher, B., Nicole, M., Calatayud, P. and Geiger, J. P. 1996. Cytochemistry of defense responses in cassava infected by Xanthomonas campestris pv. manihotis. Can. J. Microbiol. 42:1131-1143.

Lema, M., Soengas, P., Velasco, P., Francisco, M. and Cartea, M. E. 2011. Identification of sources of resistance to Xanthomonas campestris pv. campestris in Brassica napus crops. Plant Dis. 95:292-297.

Li, X., Xia, B., Jiang, Y., Wu, Q., Wang, C., He, L., Peng, F. and Wang, R. 2010. A new pathogenesis-related protein, LrPR4, from Lycoris radiate, and its antifungal activity against Magnaporthe grisea. Mol. Biol. Rep. 37:995-1001.

Lummerzheim, M., de Oliveira, D., Castresana, C., Miguens, F. C., Louzada, E., Roby, D., van Montagu, M. and Timmerman, B. 1993. Identification of compatible and incompatible interactions between Arabidopsis thaliana and Xanthomonas campestris pv. campestris and characterization of the hypersensitive response. Mol. Plant-Microbe Interact. 6:532-544.

Luo, Y., Shang, J., Zhao, P., Xi, D., Yuan, S. and Lin, H. 2011. Application of jasmonic acid followed by salicylic acid inhibits Cucumber mosaic virus replication. Plant Pathol. J. 27:5358.

Mur, L. A. J., Kenton, P., Atzorn, R., Miersch, O. and Wasternack, C. 2006. The outcomes of concentration-specific interactions between salicylate and jasmonate signaling include synergy, antagonism, and oxidative stress leading to cell death. Plant Physiol. 140:249-262.

Mysore, K. S. and Ryu, C. M. 2004. Nonhost resistance: how much do we know? Trends Plant Sci. 9:97-104.

Newman, M. A., Conrads-Strauch, J., Scofield, G., Daniels, M. J. and Dow, J. M. 1994. Defense-related gene induction in Brassica campestris in response to defined mutants of Xanthomonas campestris with altered pathogenicity. Mol. Plant-Microbe Interact. 7:553-563.

Oh, S. K., Lee, S., Chung, E., Park, J. M., Yu, S. H., Ryu, C. M. and Choi, D. 2006. Insight into type I and II nonhost resistance using expression patterns of defense-related genes in tobacco. Planta 223:1101-1107.

Palva, T. K., Holmström, K.-O., Heino, P. and Palva, E. P. 1993. Induction of plant defense responses by exoenzymes of Erwinia carotovora subsp. carotovora. Mol. Plant-Microbe Interact. 6:190-196.

Park, Y. S., Jeon, M. H., Lee, S. H., Moon, J. S., Cha, J. S., Kim, H. Y. and Cho, T. J. 2005. Activation of defense responses in Chinese cabbage by a nonhost pathogen, Pseudomonas syringae pv. tomato, J. Biochem. Mol. Biol. 38:748-754.

Ramos, L. J. and Volin, R. B. 1987. Role of stomatal opening and frequency on infection of Lycopersicon spp. by Xanthomonas campestris pv. vesicatoria. Phytopathology 77:1311-1317.

Sanchez-Vallet, A., Ramos, B., Bednarek, P., López, G., Piœlewska-Bednarek, M., Schulze-Lefert, P. and Molina, A. 2010. Tryptophan-derived secondary metabolites in Arabidopsis thaliana confer non-host resistance to necrotrophic Plectospharella cucumerina fungi. Plant J. 63:115-127. 
Savchenko, T., Walley, J. W., Chehab, E. W., Xiao, Y., Kaspi, R., Pye, M. F., Mohamed, M. E., Lazarus, C. M., Bostock, R. M. and Dehesh, K. 2010. Arachidonic acid: an evolutionarily conserved signaling molecule modulates plant stress signaling networks. Plant Cell 22:3193-3205.

Simpson, R. B. and Johnson, L. J. 1990. Arabidopsis thaliana as a host for Xanthomonas campestris pv. campestris. Mol. PlantMicrobe Interact. 3:233-237.

Stall, R. E., Jones, J. B. and Minsavage, G. V. 2009. Durability of resistance in tomato and pepper to Xanthomonads causing bacterial spot. Annu. Rev. Phytopathol. 47:265-284.

Truman, W., Bennett, M. H., Kubigsteltig, I., Turnbull, C. and Grant, M. 2007. Arabidopsis systemic immunity uses conserved defense signaling pathways and is mediated by jasmonates. Proc. Natl. Acad. Sci. USA 104:1075-1080.

Vakili, N. G. 1967. Importance of wound in bacterial spot (Xanthomonas vesicatoria) of tomatoes in the field. Phytopathology 57:1099-1103.

van Loon, L. C., Rep, M. and Pieterse, C. M. J. 2006. Significance of inducible defense-related proteins in infected plants. Аnпи.
Rev. Phytopathol. 44:135-162.

van Loon, L. C. and van Strien, E. A. 1999. The families of pathogenesis-related proteins, their activities, and comparative analysis of PR-1 type proteins. Physiol. Mol. Plant Pathol. 55:8597.

Wang, N., Xiao, B. and Xiong, L. 2011. Identification of a cluster of PR4-like genes involved in stress responses in rice. J. Plant Physiol. 168:2212-2224.

Yamamoto, Y., Kobayashi, Y. and Matsumoto, H. 2001. Lipid peroxidation is an early symptom triggered by aluminum, but not the primary cause of elongation inhibition in pea roots. Plant Physiol. 125:199-208.

Yun, B. W., Atkinson, H. A., Gaborit, C., Greenland, A., Read, N. D., Pallas, J. A. and Loake, G. J. 2003. Loss of actin cytoskeletal function and EDS1 activity, in combination, severely compromises non-host resistance in Arabidopsis against wheat powdery mildew. Plant J. 34:768-777.

Zhang, C., Gutsche, A. T. and Shapiro, A. D. 2004. Feedback control of the Arabidopsis hypersensitive response. Mol. PlantMicrobe Interact. 17:357-365. 